\title{
PERANAN BADAN WAKAF INDONESIA DALAM PENGEMBANGAN WAKAF UANG DI INDONESIA MENURUT UNDANG-UNDANG NOMOR 41 TAHUN 2004 TENTANG WAKAF
}

\author{
Uswatun Hasanah ${ }^{1}$
}

\begin{abstract}
With the issuance of Law Number 41 Year 2004 on Waqf and the Government Regulation Number 42 Year 2006 on the Implementation of Law Number 41 Year 2004 on Waqf, it is expected that the Indonesian waqf activities may be well developed, so it can function as a way to improve the welfare of the community. In Law No. 41 of 2004, it is governed not only the fixed object, but also moving objects including cash waqf. Cash waqf is the new thing among Muslims in Indonesia. Currently those familiar to Muslims in Indonesia are only waqf of fixed objects in particular waqf of land. Though cash waqf has been applied in the Muslim world since Mamalik Dynasty, even at this moment the cash waqf has been being developed in some countries and they have successfully developed the waqf. Cash waqf needs professional nazhir who understand the problem of investment. Therefore, in order that nazhir of cash waqf can manage the waqf mandated and able to forward the investment returns to the eligible beneficiaries, coaching nazhir especially nazhir of cash waqf must be established. The Agency obliged to do development on the nazhir including nazhir of cash waqf is Indonesian Waqf Board of. In Article 49 paragraph (1) letter a, it is mentioned that one of the duties and authorities of Indonesian Waqf Board is to guide the Nazhir in managing and developing the waqf property. Even in Article 48 paragraph (1) it is stated that the management and development of waq property must be guided by the regulations of Indonesian Waqf Board. This indicates that Indonesian Waqf Board has a major role towards the success of nadzhir especially nazhir of cash waqf, in managing money is mandated to him.
\end{abstract}

Keywords: Indonesian waqf board, nazhir, nazhir of cash waqf

\begin{abstract}
Abstrak
Dengan dikeluarkannya Undang-Undang Nomor 41 Tahun 2004 tentang Wakaf dan Peraturan Pemerintah Nomor 42 Tahun 2006 tentang Pelaksanaan UndangUndang Nomor 41 Tahun 2004 tentang Wakaf, diharapkan bahwa kegiatan wakaf Indonesia dapat berkembang dengan baik, sehingga dapat berfungsi sebagai cara untuk meningkatkan kesejahteraan masyarakat. Dalam Undang-Undang Nomor 41 Tahun 2004, itu diatur tidak hanya obyek tetap, tetapi juga benda bergerak termasuk wakaf tunai. Wakaf tunai adalah hal baru di kalangan umat Islam di Indonesia. Saat ini mereka yang akrab dengan Muslim di Indonesia hanya wakaf

1 Guru Besar Hukum Islam Fakultas Hukum Universitas Indonesia. Alamat kontak: uswahhdm@yahoo.co.id.
\end{abstract}


benda tetap dalam wakaf khususnya tanah. Meskipun wakaf tunai telah diterapkan di dunia Muslim sejak Dinasti Mamalik, bahkan saat ini wakaf tunai telah dikembangkan di beberapa negara dan mereka telah berhasil mengembangkan wakaf tersebut. Wakaf tunai perlu Nazhir profesional yang memahami masalah investasi. Oleh karena itu, agar Nazhir wakaf dapat mengelola kas wakaf yang diamanatkan dan mampu meneruskan hasil investasi kepada penerima yang berhak, pembinaan Nazhir khususnya Nazhir wakaf tunai harus ditetapkan. Dewan wakaf wajib melakukan pengembangan pada Nazhir termasuk Nazhir dari wakaf tunai. Dalam Pasal 49 ayat (1) huruf a, disebutkan bahwa salah satu tugas dan wewenang Dewan Wakaf Indonesia adalah membimbing Nazhir dalam mengelola dan mengembangkan properti wakaf. Bahkan dalam Pasal 48 ayat (1) disebutkan bahwa pengelolaan dan pengembangan harta benda wakaf harus berpedoman pada peraturan Dewan Wakqf Indonesia. Hal ini menunjukkan bahwa Dewan Wakqf Indonesia memiliki peran besar terhadap keberhasilan nadzhir khususnya Nazhir wakaf uang tunai dalam mengelola uang diamanatkan kepadanya.

Kata kunci: badan wakaf Indonesia, nazhir, wakaf uang

\section{Pendahuluan}

Wakaf merupakan salah satu lembaga sosial ekonomi Islam yang potensinya belum sepenuhnya digali dan dikembangkan. Pada akhir-akhir ini upaya untuk mengembangkan potensi wakaf ini terus menerus dilakukan melalui berbagai kajian, baik dari segi peranannya dalam sejarah, maupun kemungkinan peranannya di masa yang akan datang. Cukup banyak pemikir-pemikir Islam khususnya pakar hukum Islam dan ekonomi Islam melakukan kajian tentang cara mengembangkan wakaf secara produktif. Kajian ini tidak hanya terjadi di universitas-universitas Islam, tetapi juga di di berbagai universitas yang ada di Amerika maupun Eropa. Di Indonesia sendiri, saat ini wakaf sudah cukup mendapat perhatian dari para ilmuwan dan para praktisi. Hal ini dibuktikan dengan adanya berbagai seminar, lokakarya dan karya ilmiah tentang wakaf baik, berupa skripsi, tesis maupun disertasi. Bahkan pada saat ini cukup banyak perguruan tinggi yang menjadikan wakaf sebagai salah satu mata kuliah seperti contohnya di Fakultas Hukum UI, Fakultas Hukum Universitas Tarumanagara, Program Studi Timur Tengah dan Islam Pascasarjana UI, Islamic Economics and Finance (IEF)Post Graduate Program Trisakti University dan lain-lain. Hal ini semakin meyakinkan masyarakat dan pemerintah bahwa wakaf merupakan salah satu lembaga sosial- ekonomi Islam yang potensial untuk dikembangkan. Perhatian Pemerintah Republik Indonesia terhadap wakaf semakin jelas setelah Departemen Agama membentuk Direktorat Pemberdayaan Wakaf dan disahkannya Undang-undang Nomor 41 Tahun 2004 Tentang Wakaf, Peraturan Pemerintah Nomor 42 Tahun 2006 Tentang Pelaksanaan Undang-undang Nomor 41 Tahun 2004 Tenang Wakaf, Peraturan Menteri Agama Nomor 4 Tahun 2009 Tentang Administrasi Pendaftaran Wakaf Uang. Bahkan pada hari Jum'at, tanggal 8 Januari 2010 Presiden Republik Indonesia, Bapak Dr. H. Susilo Bambang 
Yudhoyono telah mencanangkan Gerakan Nasional Wakaf Uang di Istana Negara. Pencanangan Gerakan Wakaf Uang tersebut diprakarsai oleh Badan Wakaf Indonesia. Dengan pencanangan wakaf uang tersebut diharapkan gerakan wakaf uang menjadi gerakan nasional yang melibatkan seluruh komponen bangsa yang ada. Gerakan ini meliputi sosialisasi, penghimpunan, pengelolaan, dan penyaluran hasil wakaf. Wakaf uang yang terkumpul nantinya akan dikelola secara produktif oleh nazhir melalui produk-produk syariah dan instrumen-instrumen keuangan syariah, baik di sektor riil maupun sektor finansial. Hasil pengelolaan wakaf uang tersebut diharapkan dapat dimanfaatkan untuk meningkatkan kesejahteraan sosial. $^{2}$

Wakaf uang adalah hal baru di kalangan umat Islam di Indonesia. Sementara ini yang dikenal umat Islam di Indonesia hanyalah wakaf benda tidak bergerak khususnya wakaf tanah. Padahal wakaf uang sudah diterapkan di Dunia Islam sejak dinasti Mamalik. Pada saat ini wakaf uang sudah dikembangkan di beberapa negara yang sudah berhasil mengembangkan wakaf produktif. Negara-negara yang wakafnya sudah dikembangkan secara produktif, pada umumnya di samping diatur dalam undang-undang, pengembangan wakaf juga didukung oleh suatu Badan atau lembaga yang khusus mengurusi wakaf, seperti yang dilakukan di Mesir, Saudi Arabia, Sudan, dan lain-lain. Sebagaimana negara-negara lain yang memiliki harta wakaf yang cukup banyak, Indonesia juga bertekad untuk mengembangkan wakaf secara produktif, karena berdasarkan data yang ada di Kementerian Agama per 23 Juli 2009, jumlah asset tanah wakaf di Indonesia lebih dari 450 lokasi, dengan luas lebih dari 2,7 milyar meter persegi. ${ }^{3}$ Sehubungan dengan hal itu, untuk memajukan dan mengembangkan perwakafan nasional, dalam Undang-undang Nomor 41 Tahun 2004 diamanatkan untuk dibentuk Badan Wakaf Indonesia. Agar masyarakat Indonesia memahami peranan Badan Wakaf Indonesia dalam pengembangan wakaf uang, menurut penulis perlu dibahas tentang "Peran Badan Wakaf Indonesia dalam pengelolaan wakaf uang menurut Undang-undang Nomor 41 Tahun 2004 Tentang Wakaf".

\section{Wakaf Uang dalam Undang-undang Nomor 41 Tahun 2004 Tentang Wakaf}

Wakaf adalah salah satu lembaga yang sangat dianjurkan dalam ajaran Islam untuk dipergunakan oleh seseorang sebagai sarana penyaluran rezeki yang diberikan oleh Allah kepadanya. Meskipun wakaf tidak jelas dan tegas disebutkan dalam al-Qur'an, tetapi ada beberapa ayat yang digunakan oleh para ahli sebagai dasar hukum disyariatkannya wakaf. Salah satu ayat yang dijadikan sandaran hukum adalah firman Allah yang artinya lebih kurang sebagai berikut:

\footnotetext{
${ }^{2}$ Mustafa Edwin Nasution, et.al., "Pencanangan Gerakan Nasional Wakaf Uang", (Jakarta: Badan Wakaf Indonesia, 2010), hal. IV.

${ }^{3}$ Ibid., hal. 12.
} 
al-Baqarah, ayat 267

\begin{abstract}
Hai orang-orang yang beriman, nafkahkanlah (di jalan Allah) sebagian yang baik-baik dari hasil usahamu dan dari apa yang Kami keluarkan dari bumi untuk kamu. Dan janganlah kamu memilih yang buruk-buruk di antaranya yang kamu nafkahkan...
\end{abstract}

Di samping beberapa ayat, ada juga beberapa Hadits yang memerintahkan manusia untuk berbuat baik kepada sesama manusia dalam masyarakat. Salah satu Hadits yang dijadikan landasan khusus perbuatan mewakafkan harta yang dimiliki seseorang adalah Hadits yang diriwayatkan oleh Jama'ah, yang mana dalam Hadits itu disebutkan bahwa Umar pernah mendapatkan sebidang tanah di Khaibar, kemudian ia bertanya (kepada Rasulullah): Ya Rasulullah, saya mendapat sebidang tanah di Khaibar, suatu harta yang belum pernah kudapat sama sekali yang lebih baik bagiku selain tanah itu, lalu apa yang hendak engkau perintahkan kepadaku? Kemudian Nabi menjawab; "Jika engkau mau, tahanlah pangkalnya dan sedekahkan hasilnya". Kemudian Umar menyedekahkannya dengan syarat tidak boleh dijual, tidak boleh dihibahkan dan tidak boleh diwariskan. Adapun hasilnya itu disedekahkan untuk orang-orang fakir dan keluarga dekat, untuk memerdekakan hamba sahaya, untuk menjamu tamu, untuk orang yang kehabisan bekal dalam perjalanan (ibnussabil) dan tidak berdosa orang yang mengurusinya itu untuk memakan sebagiannya dengan cara yang wajar dan untuk memberi makan (kepada keluarganya) dengan syarat jangan dijadikan hak milik. Dalam satu riwayat disebutkan bahwa harta yang diwakafkan tersebut tidak boleh dikuasai pokoknya. ${ }^{4}$

Sepanjang sejarah Islam, wakaf telah berperan sangat penting dalam pengembangan kegiatan-kegiatan sosial ekonomi dan kebudayaan masyarakat Islam dan telah menfasilitasi sarjana dan mahasiswa dengan sarana dan prasarana yang memadai yang memungkinkan mereka melakukan berbagai kegiatan seperti riset dan menyelesaikan studi mereka. Cukup banyak program-program yang didanai dari hasil wakaf seperti penulisan buku, penerjemahan dan kegiatankegiatan ilmiah dalam berbagai bidang termasuk bidang kesehatan. Wakaf tidak hanya mendukung pengembangan ilmu pengetahuan, tetapi juga menyediakan berbagai fasilitas yang diperlukan mahasiswa maupun masyarakat. Sebagai contoh misalnya di bidang kesehatan, lembaga wakaf juga menyediakan fasilitas-fasilitas untuk meningkatan kesehatan masyarakat dan fasilitas pendidikan dengan pembangunan rumah sakit, sekolah medis, dan pembangunan industri obat-obatan serta kimia. Dilihat dari segi bentuknya wakaf juga tidak terbatas pada benda tidak bergerak,tetapi juga benda bergerak seperti uang dan saham. Di beberapa negara seperti Mesir, Yordania, Saudi Arabia, Turki, wakaf selain berupa sarana dan prasarana ibadah dan pendidikan juga beruapa tanah pertanian, perkebunan, flat, uang, saham, real estate dan lain-lain yang semuanya dikelola secara produktif.

${ }^{4}$ Muhammad bin Ali bin Muhammad al-Syaukany, "Nail al-Authar", Jilid VI, (Mesir: Mustafa al-Babi al-Halaby, t.t.), hal. 127. 
Dengan demikian hasilnya benar-benar dapat dipergunakan untuk mewujudkan kesejahteraan umat.

Wakaf uang sebenarnya sudah lama diterapkan di dunia Islam. Hal ini tidak berarti semua ulama Fikih membolehkan wakaf uang, karena ada pula beberapa ulama yang tidak membolehkan wakaf uang. Untuk mengkaji hukum wakaf uang, sebelumnya seseorang harus memahami terlebih dahulu rukun-rukun wakaf. Para ulama sepakat bahwa dalam pembentukan wakaf diperlukan beberapa rukun. Menurut 'Abdul Wahhab Khallaf, rukun wakaf ada empat: (1) Orang yang berwakaf atau wakif, yakni pemilik harta benda yang melakukan tindakan hukum; (2) Harta yang diwakafkan atau mauquf bih sebagai obyek perbuatan hukum; (3) Tujuan wakaf atau yang berhak menerima, yang disebut mauquf 'alaih; dan (4) Pernyataan wakaf dari wakif yang disebut sighat atau ikrar wakaf. ${ }^{5}$ Dari ke empat rukun tersebut, mauquf bih merupakan salah satu rukun yang relevan dengan topik yang sedang dikaji. Harta yang diwakafkan merupakan hal yang sangat penting dalam perwakafan, namun demikian harta yang diwakafkan tersebut baru sah sebagai harta wakaf, kalau benda tersebut memenuhi syarat. Adapun syarat-syarat itu antara lain adalah sebagai berikut:

1) Benda yang diwakafkan harus bernilai ekonomis, tetap zatnya dan boleh dimanfaatkan menurut ajaran Islam dalam kondisi apapun. ${ }^{6}$ Namun dalam Qanun yang ada di Mesir, wakaf (benda yang diwakafkan) tidak hanya dibatasi pada benda-benda tidak bergerak, tetapi juga benda-benda bergerak. $^{7}$ Benda yang diwakafkan harus jelas wujudnya dan pasti batasbatasnya. Syarat ini dimaksudkan untuk menghindari perselisihan dan permasalahan yang mungkin terjadi di kemudian hari setelah harta tersebut diwakafkan. Dengan kata lain persyaratan ini bertujuan untuk menjamin kepastian hukum dan kepastian hak bagi mustahik untuk memanfaatkan benda tersebut. ${ }^{8}$

2) Harta yang diwakafkan itu harus benar-benar kepunyaan wakif secara sempurna, artinya bebas dari segala beban. ${ }^{9}$

3) Benda yang diwakafkan harus kekal. Pada umumnya para ulama berpendapat bahwa benda yang diwakafkan zatnya harus kekal. ${ }^{10}$ Ulama

${ }^{5}$ Abdul Wahhab Khallaf, “Ahkam al-Waqf”, (Mesir: Matba'ah al-Misr, 1951), hal. 24.

${ }^{6}$ Muhammad Salam Madkur, "Ahkam al-Usrat fi al- Islam”, (Kairo: Dar al-Nahdat al'Arabiyyat, 1970), hal. 304. 185.

${ }^{7}$ Wahbah Zuhaily, "Fiqh al-Islamy wa Adillatuhu”, juz VIII, (Mesir: Dar al-Fikr, t.t.,), hal.

${ }^{8}$ Ibid.

9 Muhammad Ubaid al-Kubaisyi Muhammad 'Ubaid 'Abdullah al-Kubaisyi, "Ahkam alWaqf fi Syari'at al-Islamiyyah”, (Baghdad: Matba'ah al-Irsyad, 1977), hal. 351

10 Muhammad Abu Zahrah, "Muhadlarah fi al-Auqaf", (Kairo: Dar al-Fikri al-'Araby, 1971 ), hal. 103. 
Hanafiyyah mensyaratkan bahwa harta yang diwakafkan itu "ain" (zatnya) harus kekal dan memungkinkan dapat dimanfaatkan terus menerus. Mereka berpendapat bahwa pada dasarnya benda yang dapat diwakafkan adalah benda tidak bergerak. Akan tetapi menurut mereka (Ulama Hanafiyyah) benda bergerak dapat diwakafkan dalam beberapa hal: Pertama, keadaan harta bergerak itu mengikuti benda tidak bergerak dan ini ada dua macam: (1) Barang tersebut mempunyai hubungan dengan sifat diam di tempat dan tetap, misalnya bangunan dan pohon. Menurut Ulama Hanafiyyah bangunan dan pohon termasuk benda bergerak yang bergantung pada benda tidak bergerak. (2) Benda bergerak yang dipergunakan untuk membantu bhenda tidak bergerak seperti alat untuk membajak, kerbau yang dipergunakan bekerja dan lain-lain. Kedua, kebolehan wakaf benda bergerak itu berdasarkan asar yang memperbolehkan wakaf senjata dan binatangbinatang yang dipergunakan untuk berperang. Sebagaimana diriwayatkan bahwa Khalid bin Walid pernah mewakafkan senjatanya untuk berperang di jalan Allah ta'ala. Ketiga, wakaf benda bergerak itu mendatangkan pengetahuan seperti wakaf kitab-kitab dan mushaf. Menurut Ulama Hanafiyyah, pengetahuan adalah sumber pemahaman dan tidak bertentangan dengan nas. Mereka menyatakan bahwa untuk mengganti benda wakaf yang dikhawatirkan tidak kekal adalah memungkinkan kekalnya manfaat. Menurut mereka mewakafkan buku-buku dan mushaf di mana yang diambil adalah pengetahuannya, kasusnya sama dengan mewakafkan dirham dan dinar. Oleh karena itu Ulama Hanafiyyah membolehkan wakaf uang. ${ }^{11}$

Di samping Mazhab Hanafi, az-Zuhri (wafat tahun $124 \mathrm{H}$ ) juga membolehkan wakaf uang. Imam al-Bukhari (wafat tahun 252) menyebutkan bahwa Imam az-Zuhri berpendapat dinar dan dirham boleh diwakafkan dengan cara dijadikan modal usaha, kemudian keuntungannya diberikan kepada mauquf 'alaih. Mazhab Maliki juga menyebutkan dengan jelas tentang bolehnya wakaf nuqud (uang). Bahkan Abu Tsaur meriwayatkan dari Syafi'i bahwa Syafi'i memperbolehkan wakaf dirham dan dinar (uang). Akan tetapi sampai kini belum ditemukan ahli fikih Mazhab Syafi'i atau lainnya yang menjelaskan maksud Imam Syafi'i apakah yang dimaksud wakaf dirham dan dinar sama dengan pendapat Mazhab Maliki atau mewakafkannya untuk disewakan buat perhiasan. ${ }^{12}$ Dari berbagai pendapat yang sudah dikemukakan, jelas bahwa cukup banyak ulama yang membolehkan wakaf uang. Pada umumnya, negara yang menerapkan wakaf uang, terlebih dahulu mereka juga sudah menerapkan wakaf benda lain.

Negara yang cukup berpengalaman dalam mengelola wakaf antara lain adalah Mesir, Saudi Arabia, Yordania, Turki, Bangladesh dan lain-lain. Menurut M.A. Mannan, Turki mempunyai sejarah terpanjang dalam pengelolaan wakaf, yang mencapai keberhasilannya di zaman Utsmaniyyah, di mana harta wakaf pada tahun 1925 diperkirakan mencapai 3/4 dari luas tanah produktif. Pusat Administrasi

${ }^{11}$ Ibid., hal. 103-104.

12 Anwar Ibrahim, Waqf an-Nuqud (Wakaf Uang) Dalam Perspektif Hukum Islam dalam Jurnal A-Awqaf, Volume 2, April, 2009, hal. 4-6. 
Wakaf dibangun kembali setelah penggusurannya pada tahun 1924. Sekarang, Waqf Bank \& Finance Corporation telah didirikan untuk memobilisasi sumbersumber wakaf dan untuk membiayai bermacam-macam jenis proyek joint venture. Wakaf di Turki, ada yang dikelola oleh Direktorat Jenderal Wakaf dan ada pula yang dikelola mutawalli. ${ }^{13}$ Dalam mengelola wakaf, Dirjen Wakaf juga melakukan kerjasama dan investasi di berbagai lembaga, antara lain: Ayvalik and Aydem Olive Oil Corporation; Tasdelen Healthy Water Corporation; Auqaf Guraba Hospital; Taksim Hotel (Sheraton); Aydin Textile Industry; Black Sea Copper Industry; Contruction and Export/Import Corporation; Turkish Auqaf Bank. $^{14}$

Turkish Auqaf Bank didirikan oleh Direktorat Jenderal pada tahun 1954. Direktorat Jenderal memiliki saham di Bank tersebut sebanyak 75\%. Bank ini merupakan salah satu bank besar di Turki dengan modal 17 Milyar TL (USD 45 juta), bank ini mempunyai 300 cabang di seluruh Turki. Laba yang dibukukan pada tahun 1983, berjumlah 2 milyar TL (USD 5 juta). Pendapatan dari bank tersebut dipergunakan untuk manajemen, perbaikan dan berbagai keperluan wakaf properti. ${ }^{15}$ Yang menjadi pertanyaan berikutnya, bagaimanakah penerapan wakaf uang di Indonesia?

Pada saat ini wakaf uang di Indonesia sudah tidak ada masalah lagi karena pada tanggal 11 Mei 2002 Komisi Fatwa Majelis Ulama Indonesia telah menetapkan fatwa tentang wakaf uang, yang isinya adalah sebagai berikut:

1) Wakaf uang (Cash Wakaf/Waqf al-Nuqud) adalah wakaf yang dilakukan seseorang, kelompok orang, lembaga atau badan hukum dalam bentuk uang tunai;

2) Termasuk ke dalam pengertian uang adalah surat-surat berharga;

3) Wakaf uang hukumnya jawaz (boleh);

4) Wakaf uang hanya boleh disalurkan dan digunakan untuk hal-hal yang dibolehkan secara syar'i. Nilai pokok wakaf uang harus dijamin kelestariannya, tidak boleh dijual, dihibahkan, dan atau diwariskan.

Sebagaimana sudah diketahui bahwa wakaf yang ada di Indonesia pada umumnya berupa benda-benda tidak bergerak. Wakaf yang jumlahnya sangat banyak tersebut pada umumnya berupa tanah, sawah, bangunan dan benda-benda tidak bergerak lainnya, yang mana untuk memeliharanya memerlukan dana yang tidak sedikit. Masalahnya lagi, masih cukup banyak nazhir yang kurang mampu untuk mendapatkan dana pemeliharaan dan pengembangan wakaf yang dikelolanya. Bahkan ada sebagian nazhir wakaf di Indonesia yang kurang memahami tugas dan kewajibannya.

${ }^{13}$ Islamic Research And Training Institute, Management and Development of Auqaf Properties, (Jeddah, Islamic Development Bank, 1987), hal. 116.

${ }^{14}$ Ibid., hal. 117.

${ }^{15} \mathrm{Ibid}$. 
Akhir-akhir ini Kementerian Agama Republik Indonesia sudah melakukan beberapa pelatihan nazhir dan sejenisnya, mudah-mudahan pemahaman nazhir tentang hak dan kewajibannya lebih meningkat sehingga mampu melaksanakan kewajibannya dengan baik dan benar. Meskipun mereka sudah memahami kewajibannya sebagai nazhir, para nazhir tetap akan menemui kesulitan dalam mengelola wakaf yang menjadi tanggungjawabnya, karena pada umumnya wakaf yang diamanahkan kepadanya adalah wakaf yang hanya berupa bangunan seperti mesjid, sekolahan, rumah yatim piatu tanpa diiringi dengan wakaf yang dapat dikembangkan secara produktif. Di Indonesia masih sedikit orang yang mewakafkan tanahnya dalam bentuk tanah pertanian, andaikatapun ada untuk mengelola tanah tersebut masih tetap memerlukan biaya yang tidak sedikit dan biaya tersebut harus diusahakan. Oleh karena itu sudah saatnya umat Islam Indonesia memikirkan cara mengelola wakaf yang ada khususnya wakaf tanah agar dapat mendatangkan kemanfaatan pada semua pihak, baik bagi wakif, mauquf 'alaih maupun masyarakat. Dari pengalaman di berbagai negara, optimalisasi pengelolaan wakaf dapat dilakukan asal ada komitmen bersama antara pemerintah dan anggota masyarakat. Adanya semangat dari masyarakat untuk mengembangkan wakaf saja tidak cukup tanpa adanya kebijakan pemerintah yang mendukungnya, demikian juga sebaliknya, kebijakan pemerintah untuk mengembangkan wakaf di Indonesia tidak akan tercapai tanpa adanya komitmen dari masyarakat karena wakaf adalah dari masyarakat, untuk masyarakat dan pengelolanyapun pada umumnya dilakukan oleh masyarakat.

Begitu pentingnya wakaf bagi kesejahteraan masyarakat Indonesia, maka Undang-undang Wakaf yang mendukung pengelolaan wakaf secara produktif sangat diperlukan. Oleh karena itu sudah selayaknya umat Islam menyambut baik Undang-Undang Wakaf. Dalam Undang-undang Wakaf tersebut sudah dimasukkan rumusan konsepsi fikih wakaf baru di Indonesia yang antara lain meliputi benda yang diwakafkan (mauquf bih); peruntukan wakaf (mauquf 'alaih); sighat wakaf baik untuk benda tidak bergerak maupun benda bergerak seperti uang dan saham; kewajiban dan hak nazhir wakaf; dan lain-lain yang menunjang pengelolaan wakaf produktif.

Dalam Undang-Undang Tentang Wakaf itu sudah diatur berbagai hal yang penting dalam pengembangan wakaf. Sebagai contoh misalnya benda wakaf yang diatur dalam Undang-Undang itu tidak hanya dibatasi pada benda tidak bergerak tetapi juga benda bergerak seperti uang, logam mulia, surat berharga, kendaraan, hak atas kekayaan intelektual, hak sewa dan benda bergerak lain sesuai dengan ketentuan syari'ah dan peraturan perundang-undangan yang berlaku.

Dalam Pasal 16 ayat (1) disebutkan bahwa harta benda wakaf terdiri:

a. benda tidak bergerak; dan

b. benda bergerak.

Sedangkan pada ayat (2) disebutkan bahwa benda tidak bergerak sebagaimana dimaksud pada ayat (1) huruf a meliputi:

a. hak atas tanah sesuai dengan ketentuan peraturan perundang-undangan yang berlaku baik yang sudah maupun yang belum terdaftar; 
b. bangunan atau bagian bangunan yang berdiri di atas tanah sebagaimana dimaksud pada huruf a;

c. tanaman dan benda lain yang berkaitan dengan tanah;

d. hak milik atas satuan rumah susun sesuai dengan ketentuan peraturan perundang-undangan yang berlaku;

e. benda tidak bergerak lain sesuai dengan ketentuan syari'ah dan peraturan perundang-undangan yang berlaku.

Adapun pada ayat (3) Pasal yang sama disebutkan bahwa benda bergerak sebagaimana dimaksud pada ayat (1) huruf $\mathrm{b}$ adalah harta benda yang tidak bisa habis karena dikonsumsi, meliputi:
a. uang;
b. logam mulia;
c. surat berharga;
d. kendaraan;
e. hak atas kekayaan intelektual;
f. hak sewa; dan
g. benda bergerak lain sesuai dengan ketentuan syari'ah dan peraturan perundang-undangan yang berlaku.

Berdasarkan pengalaman di Negara lain, wakaf uang membuka peluang yang unik untuk menciptakan investasi guna memberikan pelayanan keagamaan, layanan pendidikan, dan layanan sosial. Tabungan orang-orang kaya dapat dimanfaatkan dengan menukarkannya dengan Cash-Waqf Certificate. Hasil pengembangan wakaf yang diperoleh dari sertifikat tersebut dapat dimanfaatkan untuk tujuan-tujuan yang bermacam-macam seperti tujuan-tujuan wakaf itu sendiri. Kegunaan lain dari Cash-Waqf Certificate adalah bahwa dia dapat mengubah kebiasaan lama di mana kesempatan wakaf seolah-olah hanya untuk orang-orang kaya saja. Karena Cash-Waqf Certificate seperti yang diterbitkan oleh Social Investment Bank dibuat dengan denominasi sekitar US \$21, maka certificate tersebut dapat dibeli oleh sebagian besar umat Islam, dan bahkan sertifikat tersebut dapat dibuat dengan pecahan yang lebih kecil lagi. Oleh karena itu menurut M.A. Mannan, upaya-upaya untuk memperkenalkan kepada khalayak tentang peran penting wakaf termasuk wakaf uang harus dilakukan. Pada saat ini, wakaf uang di Bangladesh sangat penting artinya dalam memobilisasi dana untuk pengembangan wakaf properti. ${ }^{16}$ Menurut penulis, model pengelolaan wakaf yang dilakukan di Bangladesh ini sangat cocok diterapkan di Indonesia, karena sebelum Prof. Mannan mengembangkan wakaf uang, permasalahan perwakafan di Bangladesh hampir sama dengan permasalahan wakaf di Indonesia. Oleh karena itu sangatlah tepat wakaf uang diatur dalam bagian tersendiri dalam UndangUndang Nomor 41 Tahun 2004 Tentang Wakaf.

${ }^{16}$ M. A. Mannan, "Cash-Waqf Certificate Global Apportunities for Developing The Social Capital Market in 21 -Century Voluntary Sector Banking", di dalam Harvard Islamic Finance Information Program-Center for Middle Eastern Studies, "Proceedings of The Third Harvard University Forum on Islamic Finance", (Cambridge: Harvard University, 1999), hal. 248. 
Dalam Pasal 28 Undang-undang Nomor 41 Tahun 2004 juga disebutkan bahwa wakif dapat mewakafkan benda bergerak berupa uang melalui lembaga keuangan syariah yang ditunjuk oleh Menteri. Yang dimaksud Menteri dalam hal ini adalah Menteri Agama. Dalam Penjelasan Pasal 28 disebutkan bahwa yang dimaksud Lembaga Keuangan Syariah adalah badan hukum Indonesia yang bergerak di bidang keuangan syariah. Pasal 29 ayat (1) menyebutkan bahwa wakaf benda bergerak berupa uang sebagaimana dimaksud dalam Pasal 28 dilaksanakan oleh wakif dengan pernyataan kehendak wakif yang dilakukan secara tertulis. Kemudian ayat (2) Pasal yang sama menyebutkan bahwa wakaf benda bergerak berupa uang sebagaimana dimaksud pada ayat (1) diterbitkan dalam bentuk sertifikat wakaf uang. Kemudian dalam ayat (3) disebutkan bahwa sertifikat wakaf uang sebagaimana dimaksud pada ayat (2) diterbitkan dan disampaikan oleh lembaga keuangan syariah kepada Wakif dan Nazhir sebagai bukti penyerahan harta benda wakaf. Ketentuan lebih lanjut mengenai wakaf benda bergerak berupa uang sebagaimana dimaksud dalam Pasal 28, Pasal 29, dan Pasal 30 diatur dalam Peraturan Pemerintah Nomoe 42 Tahun 2006 Tentang Pelaksanaan Undang-undang Nomor 41 Tahun 2004 Tentang Wakaf.

Dalam Pasal 22 ayat (1) Peraturan Pemerintah (selanjutnya disebut PP) Nomor 42 Tahun 2006 Tentang Pelaksanaan Undang-Undang Nomor 41 Tahun 2004 Tentang Wakaf disebutkan bahwa "Wakaf uang yang dapat diwakafkan adalah mata uang rupiah". Apabila uang yang akan diwakafkan masih dalam mata uang asing, maka harus dikonversi terlebih dahulu ke dalam rupiah. Hal ini disebutkan dalam ayat (2). Adapun cara mewakafkan uang disebutkan dalam ayat (3) Pasal 22 sebagai berikut, Wakif yang akan mewakafkan uangnya diwajibkan untuk:

a. hadir di Lembaga Keuangan Penerima Wakaf Uang (LKS-PWU) untuk menyatakan kehendak wakaf uangnya;

b. menjelask an kepemilikan dan asal-usul uang yang akan diwakafkan;

c. menyetorkan secara tunai sejumlah uang ke LKS-PWU;

d. Mengisi formulir pernyataan kehendak Wakif yang berfungsi sebagai AIW.

Dalam hal Wakif tidak dapat hadir sebagaimana dimaksud pada ayat (3) huruf a, maka Wakif dapat menunjuk wakil atau kuasanya. Hal ini disebutkan dengan jelas dalam Pasal 22 ayat (4). Dalam ayat (5) Pasal 22 disebutkan bahwa Wakif dapat menyatakan ikrar wakaf benda bergerak berupa uang kepada Nazhir di hadapan PPAIW yang selanjutnya Nazhir menyerahkan AIW tersebut kepada LKS-PWU. Kemudian wakif dapat mewakafkan benda bergerak berupa uang melalui LKS (Lembaga Keuangan Syariah) yang ditunjuk Menteri (Menteri Agama) sebagai LKS pengumpul Wakaf Uang (Pasal 23).

Pada saat ini sudah ada lima Bank Syariah yang ditunjuk oleh Menteri Agama RI sebagai LKS Penerima Wakaf Uang, yakni PT. Bank Negara Indonesia (PERSERO) Tbk. Divisi Syariah dengan Keputusan Menteri Agama RI Nomor 92 Tahun 2008; PT. Bank Muamalat Indonesia Tbk. Dengan Keputusan Menteri Agama RI Nomor 93 Tahun 2008; PT. Bank DKI Jakarta dengan Keputusan Menteri Agama RI Nomor 94 Tahun 2008; PT. Bank Syariah Mandiri dengan 
Keputusan Menteri Agama Nomor 95 Tahun 2008; dan PT. Bank Mega Syariah Indonesia dengan Keputusan Menteri Agama RI Nomor 96 Tahun 2008. ${ }^{17}$

Adapun tugas LKS-PWU menurut Pasal 25 Peraturan Pemerintah Nomor 42 Tahun 2006 adalah:

a. Mengumumkan kepada publik atas keberadaannya sebagai LKS Penerima Wakaf Uang;

b. Menyediakan blanko Sertifikat Wakaf Uang;

c. Menerima secara tunai wakaf uang dari wakif atas nama nazhir;

d. Menempatkan uang wakaf ke dalam rekening titipan (wadiah) atas nama nazhir yang ditunjuk wakif;

e. Menerima pernyataan kehendak wakif yang dituangkan secara tertulis dalam formulir pernyataan kehendak wakif;

f. Menerbitkan sertifikat wakaf uang serta menyerahkan sertifikat tersebut kepada wakif dan menyerahkan tembusan sertifikat kepada nazhir yang ditunjuk oleh wakif; dan

g. Mendaftarkan wakaf uang kepada Menteri atas nama Nazhir.

Yang menjadi pertanyaan berikutnya adalah, siapakah yang menjadi Pejabat Pembuat Akta Ikrar Wakaf (PPAIW) menurut Undang-Undang Nomor 41 Tahun 2004 dan Peraturan Pemerintah Nomor 42 Tahun 2006. Sebelum ada UndangUndang Nomor 41 tahun 2004, yang menjadi PPAIW adalah Kepala Kantor Urusan Agama Kecamatan. Namun pada saat ini menurut PP Nomor 42 Pasal 37 adalah sebagai berikut:

(1) PPAIW harta benda wakaf tidak bergerak berupa tanah adalah Kepala KUA dan/atau pejabat yang menyelenggarakan urusan wakaf.

(2) PPAIW harta benda wakaf bergerak selain uang adalah Kepala KUA dan/atau pejabat lain yang ditunjuk oleh Menteri.

(3) PPAIW harta benda wakaf bergerak berupa uang adalah Pejabat Lembaga Keuangan Syariah paling rendah setingkat Kepala Seksi LKS yang ditunjuk Menteri.

(4) Ketentuan sebagaimana dimaksud pada ayat (1), ayat (2) dan ayat (3) tidak menutup kesempatan bagi wakif untuk membuat AIW di hadapan Notaris.

(5) Persyaratan Notaris sebagai PPAIW ditetapkan oleh Menteri.

Yang menjadi pertanyaan berikut adalah, bagaimana tatacara pendaftaran harta benda wakaf berupa uang? Dalam Pasal 43 ayat (1) disebutkan bahwa LKS atas nama Nazhir mendaftarkan wakaf uang kepada Menteri paling lambat 7 (tujuh) hari kerja sejak diterbitkannya sertifikat wakaf uang. Kemudian ayat (2) menyebutkan "Pendaftaran wakaf uang dari LKS-PWU sebagaimana dimaksud pada ayat (1) ditembuskan kepada BWI untuk diadministrasikan. Dalam Pasal 43 ayat (3) disebutkan bahwa ketentuan lebih lanjut mengenai pendaftaran wakaf uang diatur dengan Peraturan Menteri.

${ }^{17}$ Data diambil dari Dokumen Badan Wakaf Indonesia, Jakarta, 2008. 
Peraturan Menteri (Agama) mengenai pendaftaran wakaf uang baru ditandatangani Menteri Agama RI pada tanggal 29 Juli tahun 2009. Sebagaimana sudah dituangkan dalam Undang-undang Nomor 41 Tahun 2004 Tentang Wakaf bahwa salah satu unsur wakaf adalah ikrar wakaf. Dalam Peraturan Menteri Agama RI Nomor 4 Tahun2009 Tentang Administrasi Pendaftaran Wakaf Uang Pasal 2 ayat (1) disebutkan bahwa ikrar wakaf dilaksanakan oleh Wakif kepada Nazhir di hadapan pejabat LKS-PWU atau Notaris yang ditunjuk sebagai PPAIW dengan disaksikan oleh 2 (dua) orang saksi. Pada ayat (2) disebutkan bahwa ikrar Wakaf sebagaimana dimaksud pada ayat (1) dilakukan setelah Wakif menyetorkan Wakaf Uang kepada LKS-PWU. Pejabat LKS-PWU atau Notaris sebagaimana dimaksud ayat (1) menerbitkan AIW yang memuat sekurangkurangnya data: nama dan identitas Wakif; nama dan identitas Nazhir; nama dan identitas saksi; jumlah nominal, asal usul uang; peruntukan dan jangka waktu wakaf. Hal ini disebutkan dalam ayat (3). Pada ayat (4) disebutkan bahwa bentuk dan spesifikasi formulir AIW sebagaimana dimaksud pada ayat (3) ditetapkan dengan Keputusan Direktorat Jenderal. Kemudian Pasal 3 ayat (1) disebutkan bahwa LKS-PWU wajib menerbitkan Sertifikat Wakaf Uang setelah Nazhir menyerahkan AIW. Kemudian pada ayat (2) disebutkan bahwa sertifikat wakaf uang diberikan kepada Wakif dan tembusannya diberikan kepada Nazhir.

Yang menjadi pertanyaan berikutnya adalah bagaimana cara pendaftarannya? Dalam bab III Peraturan Menteri Agama Nomor 4 Tahun 2009, Pasal 4 ayat (1) disebutkan bahwa LKS-PWU atas nama Nazhir mendaftarkan wakaf uang kepada Menteri melalui kantor Departemen Agama Kabupaten/kota selambat-lambatnya 7 (tujuh) hari kerja sejak diterbitkannya SWU dengan tembusan kepada BWI setempat. Pada ayat (2) diatur bahwa pendaftaran wakaf uang sebagimana dimaksud pada ayat (1) disertai dengan salinan/fotocopy AIW dan SWU yang disahkan oleh LKS-PWU penerbit. Dalam hal tidak terdapat kantor perwakilan BWI di kabupaten/kota, tembusan sebagaimana dimaksud pada ayat (1) disampaikan kepada BWI provinsi. Hal ini disebutkan pada ayat (3). Pada ayat (4) Pasal yang sama disebutkan juga bahwa dalam hal tidak terdapat kantor perwakilan BWI di kabupaten/kota dan provinsi tembusan sebagimana dimaksud pada ayat (1) disampaikan kepada BWI Pusat.

Dalam Pasal 4 ayat (1) disebutkan bahwa Kepala Kantor Departemen Agama Kabupaten/Kota menerbitkan bukti pendaftaran wakaf uang. Ayat (2) Pasal yang sama menyebutkan bahwa bukti pendaftaran wakaf uang sebagaimana dimaksud pada ayat (1) memuat a. Identitas LKS-PWU; b. Jumlah nominal wakaf uang; c. Asal-usul uang; d. Peruntukan wakaf; jangka waktu wakaf uang; nomor sertifikat wakaf uang; dan nomor pendaftaran. Pendaftaran wakaf uang sebagaimana dimaksud dalam Pasal 4 dicatat dalam Buku Pendaftaran.

Apabila berbagai peraturan yang berkenaan dengan wakaf khususnya wakaf uang diperhatikan dengan seksama, tampak bahwa tugas nazhir maupun orang yang bertugas di LKS tidaklah ringan, karena mereka berkewajiban menjaga harta wakaf yang diamanatkan kepadanya. Keberadaan LKS dalam penghimpunan dana wakaf uang diperkuat dengan Undang-Undang Nomor 21 Tahun 2008 Pasal 4 
ayat (3) disebutkan bahwa Bank Syariah dan $\mathrm{UUS}^{18}$ dapat menghimpun dana sosial yang berasal dari wakaf uang dan menyalurkannya kepada pengelola wakaf (nazhir) sesuai dengan kehendak pemberi wakaf (wakif). Dengan dimasukkannya wakaf dalam beberapa Undang-Undang menunjukkan bahwa wakaf merupakan lembaga Islam yang harus dikelola secara professional oleh nazhir berkompeten dengan berdasarkan peraturan perundang-Undangan yang ada.

Wakaf uang penting sekali untuk dikembangkan di Indonesia di saat kondisi perekonomian kian memburuk. Jika umat Islam mampu melaksanakannya dalam skala besar maka akan terlihat implikasi positif dari kegiatan wakaf uang tersebut. Wakaf uang mempunyai peluang yang unik bagi terciptanya investasi di bidang keagamaan, pendidikan, dan pelayanan sosial. Pendapatan yang diperoleh dari pengelolaan wakaf-wakaf tersebut dapat dibelanjakan untuk berbagai tujuan yang berbeda-beda, seperti keperluan pendidikan, kesehatan, pemberdayaan ekonomi masyarakat, untuk pemeliharaan harta-harta wakaf, dan lain-lain. Jika ada lembaga wakaf yang mampu mengelola wakaf uang secara professional, maka lembaga ini merupakan sarana baru untuk meningkatkan kesejahteraan umat.

Dalam berwakaf uang, wakif tidak boleh langsung menyerahkan uang yang diwakafkan kepada nazhir yang ditunjuk, tetapi harus melalui Lembaga Keuangan Syariah yang sudah ditunjuk oleh Menteri atas dasar dan pertimbangan Badan Wakaf Indonesia. Hal ini dengan tegas disebutkan dalam Peraturan Pemerintah (PP) Nomor 42 Tahun 2006. Pada saat ini sudah ada lembaga keuangan syariah yang ditunjuk Menteri Agama untuk menerima wakaf uang, yakni Bank Muamalat Indonesia, Bank Syariah Mandiri, BNI Syariah, Bank DKI Syariah, dan Bank Mega Syariah Indonesia. ${ }^{19}$ Hal ini menunjukkan bahwa berarti bahwa pada saat ini dasar hukum pengembangan wakaf di Indonesia sudah jelas dan tegas.

Wakaf uang penting sekali untuk dikembangkan di Indonesia di saat kondisi perekonomian yang belum membaik sebagaimana diharapkan oleh seluruh bangsa Indonesia. Hal ini disebabkan karena wakaf uang, apabila dikelola secara professional, hasilnya dapat dipergunakan untuk menyelesaikan berbagai masalah sosial dan ekonomi yang dihadapi oleh bangsa Indonesia. Meskipun wakaf sudah lama dikenal di Indonesia, namun wakaf uang baru dikenalkan di Indonesia akhirakhir ini, bahkan ada sebagian masyarakat yang belum mengenalnya. Berbeda dengan wakaf tanah, pengelolaan wakaf uang tidak mudah tetapi memerlukan kemampuan nazhir untuk melakukan investasi uang yang diwakafkan. Pada saat ini pada umumnya nazhir yang ada di Indonesia adalah nazhir yang mengelola wakaf tanah, dan cara mengelolanyapun bersifat konsumtif. Hal ini menunjukkan bahwa para nazhir belum mampu mengelola wakaf secara produktif. Untuk

${ }^{18}$ Menurut Pasal 1 angka 10 Undang-undang Nomor 21 Tahun 2008 Tentang Perbankan Syariah, yang dimaksud dengan UUS atau Unit Usaha Syariah adalah unit kerja dari kantor pusat Bank Umum Konvensional yang berfungsi sebagai kantor induk dari kantor atau unit yang melaksanakan kegiatan usaha berdasarkan Prinsip Syariah, atau unit kerja di kantor cabang dari suatu Bank yang berkedudukan di luar negeri yang yang melaksanakan kegiatan usaha secara konvensional yang berfungsi sebagai kantor induk dari kantor cabang pembantu syariah dan/atau unit syariah

\footnotetext{
${ }^{19}$ Mustafa Edwin Nasution, at.al., Op. Cit., hal. 13.
} 
meningkatkan kemampuan nazhir dalam mengelola wakaf, khususnya wakaf wakaf uang diperlukan suatu badan yang bertanggungjawab untuk melakukan pembinaan nazhir.

\section{Nazhir Wakaf: Kewajiban dan Hak-haknya}

Dalam Pasal 1 angka 1 Undang-undang Nomor 41 Tahun 2004 Tentang Wakaf disebutkan bahwa nazhir adalah pihak yang menerima harta benda wakaf dari wakif untuk dikelola dan dikembangkan sesuai dengan peruntukannya. Dalam kitab fiqh masalah nazhir ini dibahas dengan judul al-Wilayat 'ala al-waqf artinya penguasaan terhadap wakaf atau pengawasan terhadap wakaf. Orang yang diserahi atau diberi kekuasaan atau diberi tugas untuk mengawasi harta wakaf itulah yang disebut nazhir atau mutawalli. Dengan demikian nazhir berarti orang yang berhak untuk bertindak atas harta wakaf, baik untuk mengurus, memelihara, mengembangkan, dan mendistribusikan hasil wakaf kepada orang yang berhak menerimanya, ataupun mengerjakan segala sesuatu yang memungkinkan harta itu tumbuh dengan baik dan kekal. ${ }^{20}$

Dari pengertian nazhir yang telah dikemukakan, tampak bahwa dalam perwakafan, nazhir memegang peranan yang sangat penting. Agar harta itu dapat berfungsi sebagaimana mestinya dan dapat berlangsung terus-menerus, maka harta itu harus dijaga, dipelihara, dan jika mungkin dikembangkan. Dilihat dari tugas nazhir, di mana dia berkewajiban untuk menjaga, mengembangkan dan melestarikan manfaat dari harta yang diwakafkan bagi orang-orang yang berhak menerimanya, jelas bahwa berfungsi dan tidak berfungsinya suatu perwakafan bergantung pada nazhir.

Walaupun para mujtahidin tidak menjadikan nazhir sebagai salah satu rukun wakaf, namun para ulama sepakat bahwa wakif harus menunjuk nazhir wakaf (pengawas wakaf) baik nazhir tersebut wakif sendiri, mauquf alaih atau pihak lain. Bahkan ada kemungkinan nazhirnya terdiri dari dua pihak yakni wakif dan mauquf alaihnya. ${ }^{21}$ Pengangkatan nazhir ini tampaknya ditujukan agar harta wakaf tetap terjaga dan terurus sehingga harta wakaf itu tidak sia-sia.

Pada umumnya para ulama membahas masalah nazhir ini dari berbagai segi, yakni dari segi (a) orang yang berhak menjadi nazhir; (b) kedudukan, kewajiban dan hak nazhir wakaf dan (c) syarat-syarat nazhir wakaf. Dalam kesempatan ini yang akan dibahas hanyalah hak dan kewajiban nazhir.

Nazhir sebagai pihak yang bertugas untuk memelihara dan mengurusi wakaf mempunyai kedudukan yang penting dalam perwakafan. Sedemikian pentingnya kedudukan nazhir dalam perwakafan, sehingga berfungsi tidaknya wakaf itu bagi mauquf 'alaih sangat bergantung pada nazhir wakaf. Meskipun demikian tidak berarti bahwa nazhir mempunyai kekuasaan mutlak terhadap harta yang

${ }^{20}$ Muhammad Ibd. Isma'il as-San'any, "Subul al-Salam”, Juz III, (Mesir: Muhammad Ali Shabih, t.t.), hal. 112 .

\footnotetext{
${ }^{21}$ Wahbah az-Zuhaili, Op. Cit., hal. 231.
} 
diamanatkan kepadanya. Pada umumnya ulama sepakat bahwa kekuasaan nazhir wakaf hanya terbatas pada pengelolaan wakaf untuk dimanfaatkan sesuai dengan tujuan wakaf yang dikehendaki wakif.

Para ulama berpendapat bahwa tugas nazhir antara lain adalah mengawasi, memperbaiki (jika rusak), mempertahankan dan mengembangkan harta wakaf. Nazhir sebagai pihak yang diserahi mengurus wakaf berkewajiban menyampaikan hasil pengembangan harta wakaf seperti hasil sewaan, hasil pertanian seperti buah-buahan, dan hasil pengembangan lainnya kepada para mustahiq (orang yang berhak menerima hasil wakaf). Oleh karena itu ia harus menjaga pokok atau asal wakaf itu dan hasilnya secara hati-hati. ${ }^{22}$ Dari pendapat ulama tersebut dapat disimpulkan bahwa tugas nazhir tidak hanya sekedar mengawasi dan memelihara harta wakaf agar tidak hilang atau rusak, akan tetapi nazhir berkewajiban untuk mengembangkan harta wakaf itu sehingga dapat lebih bermanfaat bagi mauquf 'alaih. Dalam suatu negara yang sudah memiliki Undang-undang atau peraturan tentang wakaf, dalam melaksanakan tugasnya, nazhir harus berdasarkan pada peraturan perundang-undangan yang ada.

Meskipun nazhir mempunyai berbagai kewajiban dan tanggungungjawab yang cukup berat, tetapi nazhir juga mempunyai hak untuk mendapatkan imbalan dari jerih payahnya. Adanya upah bagi nazhir ini telah dipraktikkan oleh 'Umar ibn Khattab, 'Ali ibn Abi Talib, dan sahabat-sahabat lain. Besarnya upah yang diterima nazhir sesuai dengan ketentuan yang telah ditetapkan wakif atau hakim. Golongan Hanafiyyah berpendapat bahwa nazhir berhak mendapatkan gaji selama ia melaksanakan segala sesuatu yang diminta saat wakaf itu terjadi. Besarnya gaji bisa sepersepuluh atau seperdelapan dan sebagainya, sesuai dengan ketentuan wakif. Namun apabila wakif tidak menetapkan upah nazhir, maka hakimlah yang menetapkan upahnya. Besarnya upah nazhir disesuaikan dengan tugas yang diberikan kepadanya. ${ }^{23}$ Pendapat Ulama Malikiyyah mengenai upah nazhir hampir sama dengan pendapat Ulama Hanafiyyah. Hanya saja sebagian Ulama Malikiyyah berpendapat bahwa jika wakif tidak menentukan upah bagi nazhir, maka hakim dapat mengambil uang untuk upah nazhir tersebut dari bait al-mal. ${ }^{24}$ Menurut Imam Ahmad r.a., nazhir berhak mendapatkan upah yang telah ditentukan oleh wakif. Jika wakif tidak menentukan upah nazhir, di kalangan Ulama Hanabilah terdapat dua pendapat. Pendapat pertama menyatakan bahwa nazhir tidak halal mendapatkan upah kecuali hanya untuk makan sepatutnya. Pendapat kedua mengatakan bahwa nazhir wajib mendapatkan upah sesuai dengan pekerjaannya. ${ }^{25}$ Dalam praktiknya, imbalan bagi nazhir wakaf memang sangat bervariasi. Pada umumnya besarnya imbalan berdasarkan pada situasi dan kondisi di suatu tempat pada suatu masa dan juga didasarkan pada ketentuan yang

\footnotetext{
${ }^{22}$ Muhammad Abu Zahrah, Op. Cit., hal. 333.

${ }^{23}$ Ibid., hal. 346.

${ }^{24}$ Ibid., hal. 347.

${ }^{25}$ Ibid., hal. 349. Lihat juga Muhammad Ubaid 'Abdullah al-Kubaisy, juz II, Op. Cit., hal.
} 219. 
ditetapkan oleh wakif maupun hakim yang bertugas di wilayah di mana wakaf itu berada. Apabila di negara yang bersangkutan sudah ada peraturan perundangundangan yang mengaturnya, seperti Indonesia, maka hak dan kewajiban nazhir tergantung pada aturan yang terdapat dalam Undang-undang yang mengatur tentang wakaf, tetapi pada umumnya nazhir wakaf menerima seperdelapan sampai dengan sepersepuluh dari hasil pengembangan harta wakaf yang dikelolanya. Hal ini sangat wajar, mengingat bahwa nazhirlah yang bertugas untuk memelihara dan mengembangkan harta wakaf.

Pada dasarnya, siapa pun dapat saja menjadi nazhir asalkan ia berhak melakukan tindakan hukum. Akan tetapi, karena tugas nazhir adalah menyangkut harta benda yang manfaatnya harus disampaikan kepada pihak yang berhak menerimanya, maka jabatan nazhir harus diberikan kepada orang yang mampu menjalankan tugasnya. Yang dimaksud mampu dalam hal ini adalah (a) mampu menjaga agar harta wakaf yang diamanatkan kepadanya tetap, tidak berkurang sedikitpun; (b) mampu mengembangkan harta benda wakaf secara produktif sehingga menghasilkan dana yang dapat digunakan untuk memberdayakan masyarakat; (c) mampu mendistribusikan hasil wakaf secara adil sehingga mereka yang menerima hasil wakaf sebagaimana mestinya. Adil merupakan salah satu syarat yang harus dimiliki seorang nazhir. Para Imam Mazhab sepakat bahwa nazhir harus memenuhi syarat-syarat adil dan mampu. Di antara para ulama berbeda pendapat mengenai ukuran adil. Jumhur ulama berpendapat bahwa yang dimaksud adil adalah mengerjakan yang diperintahkan dan menjauhi yang dilarang menurut syari'at. Adapun yang dimaksud dengan kifayah (mampu) ialah kekuatan seseorang dan kemampuannya untuk mentasarrufkan apa yang dijaganya. Kemampuan di sini dituntut adanya taklif yakni dewasa dan berakal. Jika tidak ada syarat adil dan mampu, hakim boleh menahan wakaf itu dari nazhir. ${ }^{26}$ Nazhir wakaf merupakan salah satu hal yang sangat penting dalam praktik perwakafan karena berkembang tidaknya suatu wakaf sangat bergantung pada nazhir. Sedangkan pengelolaan wakaf yang baik harus menggunakan manajemen yang baik, sesuai dengan situasi dan kondisi dan tidak melanggar ajaran Islam. Pengelolaan wakaf dengan menggunakan manajemen yang baik ini sudah dilaksanakan di berbagai Negara seperti Mesir, Saudi Arabia, Yordania dan lain-lain. Di negara-negara yang wakafnya dapat berkembang dengan baik, pada umumnya wakaf dikelola oleh suatu badan, majelis atau lembaga yang khusus bertugas untuk mengembangkan perwakafan. Agar perwakafan di Indonesia dapat berkembang dengan baik, perwakafan di Indonesia harus mendapat perhatian khusus baik dari Pemerintah maupun masyarakat. Dalam Pasal 47 ayat (1) Undang-undang Nomor 41 Tahun 2004 tentang Wakaf disebutkan bahwa dalam rangka memajukan dan mengembangkan perwakafan nasional, dibentuk Badan Wakaf Indonesia. Yang harus dibahas selanjutnya adalah peran Badan Wakaf Indonesia dalam pembinaan nazhir.

\footnotetext{
${ }^{26}$ Wahbah az-Zuhaili, Op. Cit., hal. 232.
} 


\section{Peran Badan Wakaf Indonesia dalam Pengembangan Wakaf Uang}

Dengan lahirnya Undang-undang Nomor 41 Tahun 2004 Tentang Wakaf dan Peraturan Pemerintah Nomor 42 Tahun 2006 Tentang Pelaksanaan Undangundang Nomor 41 Tahun 2004 Tentang Wakaf, diharapkan perwakafan di Indonesia dapat berkembang dengan baik sehingga berfungsi untuk meningkatkan kesejahteraan masyarakat. Agar perwakafan bisa maju dan berkembang, diperlukan suatu badan yang khusus bertugas dan berwenang untuk melakukan pembinaan terhadap para pengelola wakaf (nazhir). Sehubungan dengan hal itu, dalam Undang-undang Tentang Wakaf disebutkan perlunya dibentuk Badan Wakaf Indonesia. Persiapan pendirian Badan Wakaf Indonesia sebenarnya sudah dilakukan oleh suatu Tim yang dibentuk Departemen Agama Republik Indonesia sebelum Rancangan Undang-undang tentang Wakaf dirumuskan. Dengan berbagai pertimbangan, pada akhirnya Pemerintah bertekad tidak hanya membentuk Badan Wakaf Indonesia, tetapi justru berusaha untuk mewujudkan Undang-undang Tentang Wakaf yang di dalamnya mengamanatkan untuk dibentuk suatu Badan yang diharapkan mampu mengembangkan perwakafan di Indonesia. Dalam Pasal 47 ayat (1) Undang-undang Tentang wakaf disebutkan bahwa dalam rangka memajukan dan mengembangkan perwakafan nasional, dibentuk Badan Wakaf Indonesia. Badan Wakaf Indonesia tersebut berkedudukan di ibukota Negara Kesatuan Republik Indonesia dan dapat membentuk perwakilan di provinsi dan/atau kabupaten/kota sesuai dengan kebutuhan (Pasal 48). Dalam Pasal 51 ayat (1) disebutkan bahwa Badan Wakaf Indonesia terdiri atas Badan Pelaksana dan Dewan Pertimbangan. Keanggotaan Badan Wakaf Indonesia diangkat untuk masa jabatan selama 3 (tiga) tahun dan dapat diangkat kembali untuk 1 (satu) kali masa jabatan.

Dalam Pasal 57 ayat (1) disebutkan bahwa untuk pertama kali pengangkatan keanggotaan Badan Wakaf Indonesia diusulkan kepada Presiden oleh Menteri (Menteri Agama). Alhamdulillah, setelah melalui proses yang cukup panjang, pada akhirnya Menteri Agama Republik Indonesia berhasil memilih calon anggota Badan Wakaf Indonesia untuk diusulkan kepada Presiden. Pada tanggal 13 Juli 2007, Keputusan Presiden Republik Indonesia tentang pengangkatan anggota Badan Wakaf Indonesia tersebut ditandatangani Presiden Susilo Bambang Yudoyono. Yang menjadi pertanyaan ummat Islam adalah tugas dan wewenang Badan Wakaf Indonesia dalam masalah perwakafan.

Di berbagai negara yang perwakafannya telah berkembang dengan baik, pada umumnya mereka mempunyai Badan Wakaf atau lembaga yang setingkat dengan Badan Wakaf, sebagai contoh misalnya Mesir, Saudi Arabia, dan Sudan. Di Mesir misalnya, Badan Wakaf sudah dibentuk sejak tahun 1971. Badan Wakaf di Mesir berada di bawah Departemen Perwakafan atau Wizaratul Auqaf. Tugas utama Badan Wakaf Mesir adalah menangani berbagai masalah wakaf dan mengembangkannya secara produktif sesuai dengan peraturan perundangundangan yang berlaku. Di samping itu Badan Wakaf Mesir juga berkewajiban mengusut wakaf yang bermasalah, mendistribusikan hasil wakaf dan melaksanakan segala kegiatan yang telah ditetapkan. Sebagai negara yang cukup berpengalaman dalam menangani masalah wakaf, Kementerian Wakaf Mesir 
menempatkan orang-orang profesional dalam Badam Wakaf tersebut. Untuk memperlancar kegiatannya, Badan Wakaf Mesir juga mengundang para profesional di luar mereka yang sudah menjadi pengurus. Badan Wakaf Mesir mempunyai wewenang untuk mengelola dan mendistribusikan hasil pengelolaan kepada mereka yang berhak dengan sebaik-baiknya, sehingga wakaf tersebut dapat berfungsi untuk menyejahterakan ummat. Kegiatan Badan Wakaf Mesir yang cukup penting dalam mengembangkan wakaf antara lain adalah kerjasama dengan perusahaan-perusahaan, rumah sakit, bank-bank, atau para pengembang untuk mengelola aset wakaf. Di samping itu, Badan Wakaf Mesir juga membeli saham dan obligasi dari perusahaan-perusahaan besar. Semua kegiatan Badan Wakaf di Mesir diatur dengan peraturan perundang-undangan yang memadai. ${ }^{27}$

Di samping Mesir, Saudi Arabia juga mempunyai semacam Badan Wakaf yang diberi nama Majelis Tinggi Wakaf. Majelis Tinggi Wakaf ada di bawah Kementerian Hajji dan Wakaf. Adapun wewenang Majelis Tinggi Wakaf antara lain adalah mengembangkan wakaf secara produktif dan mendistribusikan hasil pengembangan wakaf kepada mereka yang berhak. Sehubungan dengan hal itu, Majelis Tinggi Wakaf juga mempunyai wewenang untuk membuat program pengembangan wakaf, pendataan terhadap aset wakaf serta memikirkan cara pengelolaannya, menentukan langkah-langkah penanaman modal, dan langkahlangkah pengembangan wakaf produktif lainnya, serta mempublikasikan hasil pengembangan wakaf kepada masyarakat. ${ }^{28}$ Selain dua negara tersebut, Sudan juga merupakan salah satu negara yang memiliki Badan Wakaf. Dalam mengembangkan wakaf, Sudan melakukan eksperimen manajemen dengan membentuk Badan Wakaf Islam yang bekerja tanpa ada keterikatan dengan Kementerian Wakaf. Wewenang yang diberikan kepada Badan Wakaf Islam antara lain menertibkan tanah-tanah wakaf dan menggalakkan tradisi berwakaf bagi para dermawan. Kebangkitan wakaf di Sudan lebih tampak lagi sejak tahun 1991 karena Kementerian memberikan beberapa keistimewaan kepada Badan Wakaf, yang antara lain terdiri dari penyediaan dana cadangan bagi lembaga wakaf yang mengelola proyek tanah produktif baik untuk pertanian, pemukiman, maupun pusat perdagangan. Dalam melaksanakan tugasnya, Badan Wakaf pada dasarnya mempunyai dua garapan, yakni pertama menggalakkan wakaf baru, dan kedua meningkatkan pengembangan harta produktif, baik itu harta wakaf yang berasal dari warisan generasi terdahulu, maupun yang diberikan negara kepada Badan Wakaf. Dari dua garapan tersebut, yang menarik dikaji adalah garapan kedua yakni pengembangan harta produktif. Sehubungan dengan tugasnya untuk mengembangkan harta wakaf, maka garapan Badan Wakaf Sudan adalah manajemen dan investasi wakaf lama yang ada di tengah-tengah masyarakat Sudan. Dalam hal ini Badan Wakaf berpedoman kepada dua hal. Dalam kondisi wakaf ditemukan akte dan dokumennya, atau diketahui syarat wakif dan tujuan wakafnya, terutama yang berkenaan dengan seluk beluk pengangkatan nazhir,

${ }^{27}$ Hasan Abdullah al-Amin (Ed.), "Idarah wa Tatsmir Mumtalakat al-Auqaf", (Jeddah: Ma'had al-Islamy li al-Buhuts wa at-Tadrib al-Bank al-Islamy li at-Tanmiyyah, 1989), hal. 344

${ }^{28}$ Ibid., hal. 324. 
maka Badan Wakaf hanya membantu nazhir dalam mengembangkan harta wakaf. Akan tetapi dalam kondisi diperlukan, Badan Wakaf juga memberi bantuan dana kepada wakaf yang ada. Hal ini untuk meningkatkan pendapatan wakaf bagi tujuan wakaf yang telah ditentukan, dengan tetap menjaga adanya nazhir khusus pada setiap harta wakaf secara independen sesuai syarat-syarat yang ditentukan dalam akte dan dokumen wakaf, dan dengan adanya pengawasan langsung dari Badan Wakaf terhadap nazhir. Dalam kondisi wakaf tidak diketahui syaratsyaratnya, maka Badan Wakaf menyalurkan untuk semua demi kebaikan. Agar wakaf produktif, Badan Wakaf mengembangkan harta wakaf itu dengan cara menyatukan semua wakaf yang tidak ada aktenya. Dalam hal ini, Badan Wakaf menjadi nazhir atas wakaf-wakaf tersebut, mengelolanya secara produktif dan menyalurkan hasilnya kepada mereka yang berhak. ${ }^{29}$

Yang menjadi pertanyaan berikutnya "bagaimana dengan Badan Wakaf Indonesia? Dalam Pasal 47 ayat (2) Undang-undang No. 41 Tahun 2004 Tentang Wakaf disebutkan bahwa Badan Wakaf Indonesia merupakan lembaga independen dalam melaksanakan tugasnya. Adapun tugas dan wewenang Badan Wakaf Indonesia disebutkan dalam Pasal 49 ayat (1). Dalam Pasal tersebut dinyatakan bahwa Badan Wakaf Indonesia mempunyai tugas dan wewenang:

a. melakukan pembinaan terhadap nazhir dalam mengelola dan mengembangkan harta wakaf;

b. melakukan pengelolaan dan pengembangan harta benda wakaf berskala nasional dan internasional;

c. memberikan persetujuan dan/atau izin atas perubahan peruntukan dan status harta benda wakaf;

d. memberhentikan dan mengganti nazhir;

e. memberikan persetujuan atas penukaran harta benda wakaf;

f. memberikan saran dan pertimbangan kepada Pemerintah dalam penyusunan kebijakan di bidang perwakafan.

Adapun ayat (2) Pasal yang sama menyebutkan bahwa dalam melaksanakan tugas sebagaimana dimaksud pada ayat (1) Badan Wakaf Indonesia dapat bekerjasama dengan instansi Pemerintah, baik Pusat maupun daerah, organisasi masyarakat, para ahli, badan internasional, dan pihak lain yang dianggap perlu. Dalam Pasal 50 disebutkan bahwa dalam melaksanakan tugas sebagaimana dimaksud dalam Pasal 49, Badan Wakaf Indonesia memperhatikan saran dan pertimbangan Menteri dan Majelis Ulama Indonesia. Sehubungan dengan tugas dan wewenangnya tersebut Badan Wakaf Indonesia merumuskan visi sebagai berikut: Terwujudnya lembaga independen yang dipercaya masyarakat, mempunyai kemampuan dan integritas untuk mengembangkan perwakafan nasional dan internasional. Adapun misinya adalah: Menjadikan Badan wakaf Indonesia sebagai lembaga profesional yang mampu mewujudkan potensi dan

\footnotetext{
${ }^{29}$ Mundzir Qahaf, "Manajemen Wakaf Produktif", diterjemahkan oleh Muhyiddin Mas Rida, Cetakan ketiga, (Jakarta: Khalifa, 2007), hal. 308-312.
} 
manfaat ekonomi harta benda untuk kepentingan ibadah dan kesejahteraan umum. $^{30}$

Dilihat dari tugas dan wewenangnya, Badan Wakaf Indonesia yang biasa disingkat dengan BWI tanggungjawabnya sangat berat. Untuk memperlancar tugas dan wewenangnya tersebut, sementara ini BWI sudah menjalin kerjasama dengan beberapa lembaga yang terkait dengan perwakafan, baik yang bersifat nasional maupun internasional. Di antara kerjasama yang sudah dilakukan BWI dengan beberapa lembaga, antara lain adalah sebagai berikut:

a. BWI melakukan MoU dengan Islamic Development Bank (IDB). Penandatanganan nota kesepahaman (MoU) antara BWI dengan IDB dilaksanakan pada tanggal 15 Juni 2009 di Jakarta. MoU yang ditandatangani oleh Ketua Pelaksana Badan Wakaf Indonesia, Prof. Dr. K.H. Tholhah Hasan dan Presiden IDB yang diwakili oleh Direktur Jenderal Islamic Research and Training Institute, Prof. Dr. Bambang Brojonegoro tersebut bertujuan mempererat hubungan bilateral dan mendukung kerjasama di berbagai bidang yang menjadi perhatian bersama antara BWI dan IDB. Dalam MoU tersebut disepakati bahwa BWI dan IDB akan bekerjasama dalam tiga hal, yakni: Pertama, melakukan investasi dan pengembangan harta wakaf. Kedua, memperkuat kemampuan dan pengalaman ilmiah di bidang perwakafan dengan cara mendukung penelitian dan studi ilmiah tentang perwakafan. Ketiga, melakukan investasi dengan tujuan untuk mendukung misi-misi kemanusiaan yang dilakukan bersama oleh kedua belah pihak. ${ }^{31}$ Kerjasama BWI dengan IDB sangat penting khususnya IRTI karena IDB adalah salah satu lembaga internasional yang berpengalaman dalam hal penelitian, pengembangan ekonomi umat, dan lain sebagainya. Cukup banyak penelitian tentang wakaf yang telah tersebar di seluruh dunia Islam termasuk di Indonesia. Sayangnya sampai ini IRTI belum melakukan penelitian diIndonesia. Dengan kerjasama tersebut, diharapkan Badan Wakaf Indonesia mampu menjalankan tugas dan fungsinya sesuai dengan peraturan perundang-undangan.

b. BWI bekerjasama dengan Badan Wakaf Qatar dan al-Amanah al-Ammah Kuwait. Dengan kedua lembaga yang ada di Timur Tengah tersebut BWI menjalin kerjasama dalam hal peningkatan sumber daya manusia dan pengembangan perwakafan. Untuk mengembangkan sumber daya manusia, BWI mengirim orang-orang yang berminat mengembangkan perwakafan dalam pelatihan manajemen dan administrasi perwakafan serta cara-cara mengembangkan harta wakaf. ${ }^{32}$

${ }^{30}$ Badan Wakaf Indonesia, "Profil Badan Wakaf Indonesia Periode 2007-2010", (Jakarta: Badan Wakaf Indonesia, 2008), hal. 10.

\footnotetext{
${ }^{31}$ Mustafa Edwin Nasution, et.al., Op. Cit., hal. 51-54.

${ }^{32}$ Ibid.
} 
c. BWI melakukan MoU dengan Kementerian Perumahan Rakyat dan Masyarakat Ekonomi Syariah. MoU tersebut dimaksudkan (a) sebagai landasan untuk mewujudkan pelaksanaan program pengembangan perumahan melalui instrumen keuangan syariah dan wakaf; (b) mengoptimalkan peran Para Pihak dalam mewujudkan pelaksanaan program pengembangan perumahan melalui instrumen Keuangan syari'ah dan wakaf. Adapun kesepakan bersama tersebut meliputi:

a. Penyediaan tanah wakaf untuk kepentingan pembangunan perumahan masyarakat berpenghasilan rendah (MBR) dan masyarakat berpenghasilan menengan (MBM);

b. Menfasilitasi dukungan pembiayaan perumahan melalui instrumen Keuangan Syariah;

c. Melakukan kajian skema pembiayaan syariah untuk pengembangan perumahan. ${ }^{33}$

d. BWI melakukan MoU dengan 5 (lima) Lembaga Keuangan Syariah Penerima Wakaf Uang (LKS-PWU), yaitu Bank Muamalat Indonesia, Bank Syariah Mandiri, Bank BNI Syariah, Bank DKI Syariah, dan Bank Mega Syariah. Kerjasama ini selain sudah diamanatkan dalam Undang-undang bahwa BWI harus bekerjama dengan Lembaga Keuangan Syariah, juga bertujuan: a. Memberikan kemudahan bagi wakif untuk menyalurkan dana wakafnya; b.emberi kemudahan bagi wakif untuk menarik dana wakafnya dalam hal wakaf uang tersebut berjangka waktu tertentu; memberi kemudahan kepada para pihak dalam hal melakukan pelaporan kepada pihak terkait sesuai dengan peraturan yang ada. ${ }^{34}$

Diharapkan berbagai MoU BWI dengan beberapa lembaga tersebut berjalan dengan lancar, sehingga akan mempercepat pengembangan wakaf produktif dan wakaf uang di Indonesia. Dengan berbagai kegiatan dan kerjasama yang dilakukan BWI dengan berbagai pihak semakin jelas peran Badan Wakaf Indonesia dalam mengembangkan wakaf khususnya wakaf uang. Dalam Pasal 48 ayat (1) Peraturan Pemerintah Nomor 42 Tahun 2006 disebutkan bahwa pengelolaan dan pengembangan harta benda wakaf harus berpedoman pada peraturan BWI. Hal ini berarti bahwa berkembangnya harta benda wakaf termasuk wakaf uang salah satunya tergantung pada kebijakan-kebijakan yang ditetapkan oleh BWI.

\section{Penutup}

Tujuan dibentuknya Badan Wakaf Indonesia adalah untuk memajukan dan mengembangkan perwakafan nasional. Melihat kondisi yang ada sekarang

\footnotetext{
${ }^{33}$ Ibid., hal. 55-56.

${ }^{34}$ Ibid., hal. 57.
} 
memang cukup sulit untuk mengembangkan wakaf secara produktif di Indonesia. Hal ini disebabkan beberapa hal antara lain terbatasnya pemahaman masyarakat tentang wakaf termasuk wakaf uang, keterbatasan kemampuan nazhir dalam mengembangkan wakaf produktif, dan belum tersosialisasinya Undang-undang Nomer 41 Tahun 2004. Agar perwakafan di Indonesia berjalan dengan baik dan benar, sudah saatnya para nazhir memahami dengan baik dan benar tentang perwakafan baik dari segi hukumnya maupun dari segi manajemennya. Substansi Undang-undang Nomort 41 Tahun 2004 sebenarnya sudah memadai untuk dijadikan payung hukum dalam pengembangan wakaf di Indonesia. Yang menjadi masalah sekarang ini adalah cara mengaplikasi wakaf uang. Sebagus apapun suatu peraturan perundang-undangan, kalau tidak disertai dengan kemampuan sumber daya manusia yang handal untuk menerapkannya, maka peraturan perundangundangan itupun akan mubadzir. Akan tetapi penulis yakin bahwa suatu saat wakaf di Indonesia akan berkembang dengan baik dan dapat meningkatkan kesejahteraan umat sesuai dengan yang diharapkan, asal ada komitmen bersama antara Badan Wakaf Indonesia, para nazhir, umat Islam dan pemerintah. 


\section{Daftar Pustaka}

\section{Buku}

Ali, Muhammad Daud. Sistem Ekonomi Islam Zakat dan Wakaf, Jakarta: UI-Press, 1988.

Amin, Hasan 'Abdullah, Idarah wa Tatsmir Mumtalakat al-Auqaf, Jeddah: al-Ma'had al- Islamy li al-Buhus wa al-Tadrib al-Bank al-Islamy li Tanmiyyah, 1989

Badan Wakaf Indonesia. Profil Badan Wakaf Indonesia Periode 2007-2010, Jakarta: Badan Wakaf Indonesia, 2008.

Al- Jaziri, Abdurrahman. Kitab al-Fiqh 'ala al-Mazahib aal-Arba'ah, Kairo: Al-Istiqamat, t.t.

Al-Jashshas, Abu Bakar Ahmad bin Ali al-Razi. Ahkam al-Qur'an, Jilid III, Beirut Dar al-Kitab al- Arabi, t.t..

Jumhuriyyah Misr al-“Arabiyyah. Qawanin al-Auqaf wa al-Hikr wa Qararat al-Tanfiziyyah, Cayro: Al-Haiah al-'Ammah li Syuun al-Matabi alAmiriyyah, 1993.

Hazairin. Demokrasi Pancasila, Jakarta: Bina Aksara, 1983

Islamic Research And Training Institute. Management and Development of Auqaf Properties, Jeddah, Islamic Development Bank, 1987.

Khallaf, Abdul Wahhab. Ahkam al-Waqf, Mesir: Mathba'ah al-Misr, 1951.

Kubaisyi, Muhammad 'Ubaid 'Abdullah. Ahkam al-Waqf fi Syari'at alIslamiyyah, Jilid II, Baghdad: Mathba’ah al-Irsyad, 1977.

Mannan, M. A., "Cash-Waqf Certificate Global Apportunities for Developing The Social Capital Market in 21 -Century Voluntary Sector Banking", di dalam Harvard Islamic Finance Information Program-Center for Middle Eastern Studies, Proceedings of The Third Harvard University Forum on Islamic Finance, Cambridge: Harvard University, 1999.

Nasution, Mustafa Edwin, et.al. Pencanangan Gerakan Nasional Wakaf Uang, Jakarta: Badan Wakaf Indonesia, 2010.

Qahaf, Mundzir. Manajemen Wakaf Produktif, diterjemahkan oleh Muhyiddin Mas Rida, Cetakan ketiga, Jakarta: Khalifa, 2007.

Shan'any, Muhammad Ibn Isma'il. Subul al-Salam, Muhammad Ali Sabih, t. t. Juz III.

Syaukani, Muhammad bin Ali bin Muhammad. Nail al-Authar, Mesir: Musthafaal-Babi al-Halaby, t.t. Jilid IV. 
Zahrah, Muhammad Abu. Muhadlarah fi al-Auqaf, Kairo: Dar al-Fikri al'Araby, 1971

Zuhaily, Wahbah. Fiqh al-Islamy wa Adillatuhu, Juz VIII. Mesir: Dar alFikri, t.t.

\section{Jurnal}

Ibrahim, Anwar, "Waqf an-Nuqud (Wakaf Uang) Dalam Perspektif Hukum Islam”, Jurnal A-Awqaf, Volume 2, April, 2009.

\section{Peraturan Perundang-undangan}

Republik Indonesia, Undang-Undang tentang Wakaf, Undang-Undang Nomor 41 Tahun 2004, LN Nomor 159 Tahun 2004, TLN Nomor 4459

Republik Indonesia, Undang-Undang tentang Perbankan Syariah, UndangUndang Nomor 21 Tahun 2008, LN Nomor 94 Tahun 2008, TLN Nomor 4867

Republik Indonesia, Peraturan Pemerintah tentang Pelaksanaan UndangUndang Nomor 41 Tahun 2004 Tentang Wakaf, Peraturan Pemerintah Nomor 42 Tahun 2006, LN Nomor 105 Tahun 2006, TLN 4667

Republik Indonesia, Peraturan Menteri Agama RI Nomor 4 Tahun2009 Tentang Administrasi Pendaftaran Wakaf Uang. 